Article

\title{
Variation in the Antibacterial and Antioxidant Activities of Essential Oils of Five New Eucalyptus urophylla S.T. Blake Clones in Thailand
}

\author{
Sapit Diloksumpun ${ }^{1}$ (D), Nalin Wongkattiya ${ }^{2}$, Kittisak Buaban ${ }^{2}$, Tharinee Saleepochn ${ }^{3}$, Panawan Suttiarporn ${ }^{4}$ (D) \\ and Suwaporn Luangkamin $5, *$ (D)
}

1 Department of Silviculture, Faculty of Forestry, Kasetsart University, Bangkok 10900, Thailand; sapit.d@ku.ac.th

2 Program in Biotechnology, Faculty of Science, Maejo University, Chiang Mai 50290, Thailand; nalin.wongkattiya@gmail.com (N.W.); kittisak.cue@gmail.com (K.B.)

3 Department of Chemistry, Faculty of Science, Kasetsart University, Bangkok 10900, Thailand; fscitna@ku.ac.th

4 Faculty of Science, Energy and Environment, King Mongkut's University of Technology North Bangkok, Rayong Campus, Rayong 21120, Thailand; panawan.s@sciee.kmutnb.ac.th

5 Department of Fundamental Science and Physical Education, Faculty of Science at Sriracha, Kasetsart University, Sriracha Campus, Chonburi 20230, Thailand

* Correspondence: suwaporn.1@ku.th

Citation: Diloksumpun, S.; Wongkattiya, N.; Buaban, K.; Saleepochn, T.; Suttiarporn, P.; Luangkamin, S. Variation in the Antibacterial and Antioxidant Activities of Essential Oils of Five New Eucalyptus urophylla S.T. Blake Clones in Thailand. Molecules 2022, 27, 680. https://doi.org/10.3390/ molecules27030680

Academic Editor: Paulo Roberto H. Moreno

Received: 12 December 2021 Accepted: 18 January 2022

Published: 20 January 2022

Publisher's Note: MDPI stays neutral with regard to jurisdictional claims in published maps and institutional affiliations.

Copyright: (C) 2022 by the authors. Licensee MDPI, Basel, Switzerland. This article is an open access article distributed under the terms and conditions of the Creative Commons Attribution (CC BY) license (https:// creativecommons.org/licenses/by/ $4.0 /)$.

\begin{abstract}
Eucalyptus oils are widely used for a variety of purposes. This study investigates the terpenoid compositions and antibacterial and antioxidant activities of eucalypt leaf oils extracted from four E. urophylla clones and one E. urophylla $\times$ E. camaldulensis hybrid clone grown in Thailand. According to GC/MS analysis, the E. urophylla oils were mainly composed of 1,8-cineole, $\alpha$-terpinyl acetate, $\beta$-caryophyllene, and spathulenol, while 1,8-cineole, $\alpha$-terpinyl acetate, $p$-cymene, and $\gamma$-terpinene were mostly identified in the hybrid oil. All eucalypt oils exhibited a significant bacteriostatic effect against Gram-positive bacteria, Streptococcus pyogenes, Staphylococcus aureus, Listeria monocytogenes, and Bacillus cereus. Only the hybrid oil had an effect on all Gram-negative bacteria tested, including Salmonella typhi, Escherichia coli, Pseudomonas aeruginosa, and Enterobacter aerogenes. These oils have antibacterial properties that vary according to their terpenoid content. Only the hybrid oil had a potent antioxidant effect, with an $\mathrm{IC}_{50}$ value of $4.21 \pm 0.35 \mathrm{mg} / \mathrm{mL}$ for free radical (DPPH) scavenging. This oil's antioxidant effect may be a result of the phenolic terpenoids, thymol and carvacrol. As a result, these oils may be a novel source of antibacterial and antioxidant agents. Additionally, the antibacterial and antioxidant capabilities of the E. urophylla $\times$ E. camaldulensis hybrid essential oil are reported for the first time.
\end{abstract}

Keywords: Eucalyptus urophylla; E. urophylla $\times$ E. camaldulensis hybrid; Eucalyptus hybrid; essential oil; antibacterial; antioxidant; terpenoid

\section{Introduction}

The Eucalyptus genus (eucalypt) is a tropical and subtropical tree in the Myrtaceae family. It consists of about 900 species, most originally from Australia [1]. Because it is fast growing, it has been broadly cultivated in many countries to utilize as wood for a diverse range of products. The eucalypt oils extracted from the leaves have excellent biological properties and are used in the pharmaceutical, agrochemical, cosmetic, and food industries [1-3]. Eucalyptus is one of Thailand's most important economic woods for pulp and paper production. It accounts for $60 \%$ of annual commercial wood production and $56 \%$ of total commercial forest plantation area, excluding para rubber wood [4]. Two of the most promising Eucalyptus species widely planted in Thailand for commercial forest plantations are E. urophylla S.T. Blake (Timor white gum, Timor mountain gum), native to Indonesia, and E. camaldulensis Dehnh. (river red gum), originally from Australia [5,6]. 
To improve tree growth and wood quality for pulpwood and solid lumber processing, as well as pest and disease resistance, several tree breeding programs for these species have been developed in various regions, including crossbreeding between E. urophylla and E. camaldulensis in Thailand $[7,8]$, to combine the desired genetic characteristics from the two different parents and to exploit heterosis, which is commonly referred to as specific crosses, and this gives individuals great advantages compared to the parent species [9]. Furthermore, the adoption of vegetative propagation to produce hybrid clones enables the capture of the total genetic variance in growth performance and wood properties and the production of a uniform raw material beneficial for industrial processes and product quality [9]. Heterosis in most hybrids between E. urophylla and E. camaldulensis has also been observed [9-11], and their promising clones have been commercially used [10,12]. Therefore, the possibility of utilizing the leaves and essential oils from the clonal plantations of Eucalyptus, which have found diverse applications in medicine, food, cosmetics, and agriculture, is worth investigating.

Hydrodistillation and steam distillation techniques are conventional techniques for isolating volatile terpenoids, which are important constituents in essential oils [13]. Due to their ease of operation and low cost, they are commonly used to extract essential oils from Eucalyptus leaves. The eucalypt leaf oils contain a variety of volatile monoterpenoids and sesquiterpenoids, the majority of which have a greater ratio of 1,8-cineole (eucalyptol). However, the dominant constituents in the oils, such as 1,8-cineole, $\gamma$-terpinene, $p$-cymene, $\alpha$-pinene, spathulenol, and citronellal, vary according to the eucalypt species and may cause the oils to have different biological activities [1,3,14]. Eucalypt oils have been used in a variety of applications due to their ease of extraction and wide range of bioactivities. These oils have been shown to have antimicrobial, antiseptic, antiviral, antioxidant, anticancer, and anti-inflammatory activities. As a result, they are used in traditional herbal medicine (to treat respiratory diseases such as the common cold, flu, and sinus congestion), aromatherapy, and food preservation, and as active ingredients in cosmetics and household products [2,3]. Furthermore, the insecticidal, acaricidal, nematicidal, and herbicidal activities of eucalypt oils have been documented. Subsequently, they are also used in agriculture as natural pesticides, nematicides, herbicides, and insecticides [1,2,14].

Currently, natural products that have antioxidant and antimicrobial properties are blended in household products, toiletries, cosmetics, or topical applications to protect lipid peroxidation and microbial contaminations. Numerous studies on the antibacterial and antioxidant properties of eucalypt oils, including E. urophylla and E. camaldulensis leaf oil, have been published [1-3,15-22]. Interestingly, the E. urophylla and E. camaldulensis oils with dominant oxygenated terpenoids, such as 1,8-cineole, spathulenol, and carvacrol, have been shown to have significant antibacterial effects on a variety of pathogenic Gram-positive and Gram-negative bacteria [1-3,15,18-21]. Additionally, our group [22] has reported that the dominant phenolic terpenoids (2.18-7.25\%), thymol and carvacrol, cause the E. camaldulensis oils to have potent antioxidant properties (DPPH radical scavenging, and $\mathrm{IC}_{50}$ values of $0.71-1.27 \mathrm{mg} / \mathrm{mL}$ ), whereas the E. urophylla oil reported by Chahomchuen et al. [18] contained a small amount of thymol $(0.13 \%)$, and was shown to have weak DPPH radical scavenging activity $\left(\mathrm{IC}_{50} 19.95 \mathrm{mg} / \mathrm{mL}\right)$. However, only a few studies of E. urophylla and E. urophylla $\times$ E. camaldulensis leaf oils have been performed [15-18,23-29]. Variations in the antibacterial and antioxidant activity of eucalypt oils, on the other hand, are highly dependent on the type and abundance of bioactive compounds, which vary depending on the genus species, genetic backgrounds, planting sites, and seasonal variations $[1,3,20,21]$.

Therefore, the purpose of this research is to examine the phytochemical components, their antibacterial properties against eight pathogenic Gram-positive and Gram-negative bacterial strains, and the antioxidant properties of eucalypt oils extracted from the leaves of four E. urophylla clones and one E. urophylla $\times$ E. camaldulensis hybrid clone grown in Thailand's Nakhon Ratchasima province. Our research is the first to examine the chemistry and bioactivities of pure and hybrid E. urophylla clones that have been registered as new clones in Thailand after being developed through a genetic improvement program 
by the Royal Forest Department (RFD) for high biomass production and good wood quality [30]. Moreover, such Eucalyptus clones providing essential oil as an important source of natural active substances may allow us to identify promising genotypes for both biomass production and the pharmaceutical, cosmetic, and household product industries.

\section{Results and Discussion}

\subsection{Extraction of Eucalypt Oils}

The clear yellowish eucalypt oils with their pleasant odor were obtained from the hydrodistillation of four E. urophylla clones (RFD 2-2, RFD 2-3, RFD 2-4, and RFD 2-6) and one hybrid clone of the E. urophylla $\times$ E. camaldulensis (RFD 2-5) leaves. The extraction yields of eucalypt oils varied between clones, ranging from 0.38 to $0.59 \%$ weight of oils per weight of dry leaves (Table 1). The hybrid clone (RFD 2-5) produced the highest yield, while the four E. urophylla clones contained less (0.38-0.54\%). The eucalypt oil yielded by the RFD 2-6 clone was the highest among the E. urophylla clones. Regardless of clonal variations, the leaf essential oil yields of all the E. urophylla clones are related to those previously reported for the E. urophylla planted in the Congo [15], Lampang province, Thailand [18], Ethiopia [23], Brazil [24], and Côte d'Ivoire [27], ranging from 0.3 to $0.6 \%$. Furthermore, the leaf essential oil yields of the E. urophylla and the E. urophylla $\times$ E. camaldulensis hybrid are higher than those reported by Li et al. [29], with 0.04 and $0.16 \%$, respectively (Table 2). The genetic variations in E. camaldulensis leaf essential oil yields have also been reported by our group [22], ranging from 1.14 to $2.07 \%$, and the oil yields were higher than E. urophylla oils. The essential oil yield from the leaves of this Eucalyptus hybrid clone was expected to be intermediate between the parental species.

Table 1. Extraction yields and terpenoids compositions (\%) of the five eucalypt oils from the leaves of E. urophylla clones (RFD 2-2, RFD 2-3, RFD 2-4, and RFD 2-6) and the E. urophylla $\times$ E. camaldulensis hybrid clone (RFD 2-5) by GC/MS.

\begin{tabular}{|c|c|c|c|c|c|c|c|c|}
\hline \multirow{2}{*}{ No. } & \multirow{2}{*}{ Compound $^{a}$} & \multirow{2}{*}{$t_{R} b$} & \multirow{2}{*}{$\mathbf{R I}^{\mathrm{c}}$} & \multicolumn{5}{|c|}{ Composition (\%) ${ }^{d}$} \\
\hline & & & & RFD 2-2 & RFD 2-3 & RFD 2-4 & RFD 2-6 & RFD 2-5 \\
\hline 1 & $\alpha$-Pinene & 7.918 & 959 & 2.93 & 2.62 & 6.47 & 0.82 & 1.26 \\
\hline 2 & p-Cymene & 11.886 & 1043 & - & 2.79 & 7.10 & 0.74 & 14.34 \\
\hline 3 & D-Limonene & 12.117 & 1048 & 1.67 & 1.31 & 2.28 & 1.43 & 3.16 \\
\hline 4 & 1,8-Cineole & 12.258 & 1051 & 22.75 & 16.34 & 24.75 & 21.07 & 22.72 \\
\hline 5 & trans- $\beta$-Ocimene & 12.446 & 1055 & - & - & - & - & 1.98 \\
\hline 6 & $\gamma$-Terpinene & 13.483 & 1077 & - & - & - & 0.24 & 17.99 \\
\hline 7 & Terpinolene & 14.774 & 1105 & - & - & - & - & 0.55 \\
\hline 8 & trans-Linalool oxide (furanoid) & 14.815 & 1105 & - & - & 0.91 & - & - \\
\hline 9 & Fenchol & 16.347 & 1138 & 0.50 & - & 1.25 & 0.26 & - \\
\hline 10 & trans-Pinocarveol & 17.372 & 1160 & 0.77 & 0.49 & 4.04 & - & - \\
\hline 11 & Pinocarvone & 18.389 & 1181 & 0.32 & - & 1.78 & - & - \\
\hline 12 & Borneol & 18.869 & 1192 & 1.08 & - & 2.04 & 0.39 & - \\
\hline 13 & Citral & 19.205 & 1199 & - & - & - & - & 0.61 \\
\hline 14 & 4-Terpineol & 19.303 & 1201 & - & 0.54 & 0.58 & - & 2.54 \\
\hline 15 & p-Cymen-8-ol & 19.605 & 1207 & - & - & - & - & 0.27 \\
\hline 16 & trans-p-Mentha-1(7),8-dien-2-ol & 19.649 & 1208 & - & - & 0.96 & - & - \\
\hline 17 & $\alpha$-Terpineol & 20.022 & 1216 & 3.23 & 1.86 & 5.56 & 2.13 & 2.10 \\
\hline 18 & cis-Sabinol & 20.840 & 1234 & - & - & - & - & 0.35 \\
\hline 19 & cis-Carveol & 21.123 & 1240 & - & - & 0.34 & - & - \\
\hline 20 & cis-p-Mentha-1(7),8-dien-2-ol & 21.593 & 1250 & - & - & 0.97 & - & - \\
\hline 21 & Carvotanacetone & 22.465 & 1268 & - & - & 0.56 & - & - \\
\hline 22 & Piperitone & 22.696 & 1273 & - & - & 0.88 & - & 0.23 \\
\hline 23 & trans-Linalool oxide acetate (pyranoid) & 23.993 & 1299 & - & - & 0.38 & - & - \\
\hline 24 & Thymol & 24.086 & 1303 & - & - & - & - & 1.26 \\
\hline 25 & Carvacrol & 24.828 & 1318 & - & 0.48 & 1.08 & - & 2.19 \\
\hline 26 & $p$-Menth-4(8)-en-2,5-diol & 25.448 & 1332 & - & - & - & - & 0.25 \\
\hline 27 & $\alpha$-Terpinyl acetate & 26.944 & 1363 & 7.72 & 4.79 & 7.02 & 5.56 & 8.66 \\
\hline 28 & $\alpha$-Copaene & 28.200 & 1388 & 0.93 & 0.83 & - & 0.58 & 0.35 \\
\hline 29 & Geranyl acetate & 28.329 & 1392 & - & - & - & 0.43 & 0.35 \\
\hline 30 & $\alpha$-Gurjunene & 29.547 & 1423 & 0.35 & 0.56 & - & - & - \\
\hline 31 & $\beta$-Caryophyllene & 30.044 & 1435 & 8.38 & 11.79 & 3.82 & 8.34 & 0.37 \\
\hline 32 & Aromadendrene & 30.836 & 1455 & - & 0.33 & - & - & 1.42 \\
\hline
\end{tabular}


Table 1. Cont.

\begin{tabular}{|c|c|c|c|c|c|c|c|c|}
\hline \multirow{2}{*}{ No. } & \multirow{2}{*}{ Compound $^{a}$} & \multirow{2}{*}{$t_{R} b$} & \multirow{2}{*}{$\mathbf{R I}^{\mathrm{c}}$} & \multicolumn{5}{|c|}{ Composition $(\%)^{d}$} \\
\hline & & & & RFD 2-2 & RFD 2-3 & RFD 2-4 & RFD 2-6 & RFD 2-5 \\
\hline 33 & Cadina-3,5-diene & 31.275 & 1466 & 0.30 & - & - & - & - \\
\hline 34 & Humulene & 31.530 & 1473 & 1.47 & 2.18 & 0.66 & 1.38 & - \\
\hline 35 & Alloaromadendrene & 31.720 & 1478 & 0.62 & 1.19 & 0.49 & 1.18 & 0.35 \\
\hline 36 & $\beta$-Cadinene & 32.240 & 1491 & 0.75 & 0.59 & - & - & - \\
\hline 37 & $\gamma$-Selinene & 32.883 & 1507 & - & 0.62 & - & 0.44 & - \\
\hline 38 & Viridiflorene & 33.015 & 1510 & - & - & - & - & 0.25 \\
\hline 39 & $\gamma$-Muurolene & 33.023 & 1511 & 1.50 & 1.71 & - & 0.34 & - \\
\hline 40 & Bicyclogermacrene & 33.190 & 1515 & 1.36 & 2.29 & 0.76 & 0.51 & 0.26 \\
\hline 41 & $\alpha$-Muurolene & 33.335 & 1519 & 0.74 & 0.59 & - & 0.42 & - \\
\hline 42 & $\delta$-Cadinene & 34.122 & 1539 & 4.83 & 4.06 & 1.22 & 1.96 & 1.59 \\
\hline 43 & trans-Calamenene & 34.236 & 1541 & 2.62 & 2.23 & 1.20 & 3.19 & 0.43 \\
\hline 44 & Zonarene & 34.302 & 1543 & 1.88 & 1.92 & 0.58 & - & - \\
\hline 45 & Cubenene & 34.666 & 1552 & 0.61 & - & - & - & 0.45 \\
\hline 46 & $\alpha$-Dehydro-ar-himachalene & 34.765 & 1555 & 0.28 & - & - & 0.27 & - \\
\hline 47 & $\alpha$-Calacorene & 34.987 & 1561 & 1.21 & 0.39 & - & 0.69 & - \\
\hline 48 & Epiglobulol & 35.811 & 1581 & - & 0.45 & - & - & 0.34 \\
\hline 49 & Maaliol & 36.105 & 1588 & 0.86 & 1.87 & 1.00 & 1.32 & - \\
\hline 50 & Spathulenol & 36.371 & 1596 & 2.05 & 3.78 & 3.35 & 11.93 & 1.34 \\
\hline 51 & Caryophyllene oxide & 36.563 & 1600 & 4.02 & 2.48 & 1.54 & 6.57 & 0.44 \\
\hline 52 & Globulol & 36.721 & 1604 & 4.80 & 5.70 & 3.84 & 5.11 & 3.49 \\
\hline 53 & Viridiflorol & 37.041 & 1613 & 2.40 & 5.01 & 3.12 & 3.94 & 0.45 \\
\hline 54 & Cubeban-11-ol & 37.142 & 1615 & 1.15 & 2.71 & 1.53 & 1.60 & 0.30 \\
\hline 55 & Ledol & 37.445 & 1623 & 0.89 & 1.04 & 0.53 & 1.10 & - \\
\hline 56 & Rosifoliol & 37.530 & 1625 & 0.71 & 2.00 & 0.89 & 1.13 & - \\
\hline 57 & Humulene oxide II & 37.625 & 1627 & 0.49 & - & - & 0.85 & - \\
\hline 58 & $\alpha$-Eudesmol & 38.180 & 1641 & 0.84 & 2.43 & 1.32 & 1.56 & 0.34 \\
\hline 59 & 1,10-Di-epi-cubenol & 38.333 & 1645 & 4.61 & 3.63 & 2.19 & 4.10 & 3.67 \\
\hline 60 & $\gamma$-Eudesmol & 38.494 & 1649 & - & - & - & - & 0.48 \\
\hline 61 & Caryophylladienol II & 38.655 & 1654 & - & - & - & 1.15 & - \\
\hline 62 & Epicubenol & 38.917 & 1660 & 3.91 & 3.06 & 1.31 & 2.98 & 0.72 \\
\hline 63 & $\delta$-Cadinol & 39.041 & 1663 & 1.87 & 1.34 & 0.60 & 1.52 & 0.27 \\
\hline 64 & $\alpha$-Copaene-11-ol & 39.155 & 1666 & - & - & - & 0.26 & - \\
\hline 65 & $\beta$-Eudesmol & 39.315 & 1670 & - & - & - & - & 1.89 \\
\hline 66 & $\alpha$-Cadinol & 39.361 & 1671 & 1.08 & 1.00 & 1.13 & 1.74 & - \\
\hline \multirow[t]{7}{*}{67} & Neointermedeol & 39.444 & 1673 & 0.59 & 0.62 & - & 0.49 & - \\
\hline & Total terpenoids & & & 99.07 & 99.62 & 100 & 99.72 & 100 \\
\hline & Total monoterpenoids & & & 40.97 & 31.22 & 68.95 & 33.07 & 80.81 \\
\hline & Total sesquiterpenoids & & & 58.10 & 68.40 & 31.08 & 66.65 & 19.20 \\
\hline & Oxygenated terpenoids & & & 66.64 & 61.62 & 75.45 & 77.19 & 55.26 \\
\hline & Phenolic terpenoids & & & 0 & 0.48 & 1.08 & 0 & 3.45 \\
\hline & Extraction yield ${ }^{\mathrm{e}}(\% w / w)$ & & & 0.48 & 0.39 & 0.38 & 0.54 & 0.59 \\
\hline
\end{tabular}

${ }^{a}$ Compound was tentatively identified by comparing it with mass spectrum data from the NIST library. ${ }^{b}$ Retention time $\left(t_{R}\right)$ in minutes. ${ }^{c}$ Retention indices (RI) in relation to n-alkanes $\left(C_{7}-C_{20}\right)$ under the same conditions $\mathrm{d} \%$ composition was the relative amount in all analyzed compounds, calculated from peak area. -: Not detected.

Table 2. Comparison of essential oil yields, main terpenoids, and antibacterial and antioxidant activities of E. urophylla leaf oils with some those of previous studies.

\begin{tabular}{|c|c|c|c|c|c|}
\hline Source & $\begin{array}{l}\text { Oil Yield } \\
(\% w / i)\end{array}$ & $\begin{array}{l}\text { Main Terpenoids } \\
\text { (\% Compositions) }\end{array}$ & $\begin{array}{l}\text { Antibacterial Activity } \\
\text { (IZD mm) }\end{array}$ & Antioxidant Activity & Author \\
\hline $\begin{array}{l}\text { Thailand } \\
\text { (E. urophylla, RFD } \\
\text { clones) }\end{array}$ & $0.39-0.54$ & $\begin{array}{c}\text { 1,8-Cineole }(\mathbf{1 6 - 2 5}) \\
\alpha \text {-Terpinyl acetate }(\mathbf{5}-\mathbf{8}) \\
\beta \text {-Caryophyllene }(\mathbf{4 - 1 2}) \\
\text { Spathulenol }(\mathbf{2}-\mathbf{1 2})\end{array}$ & $\begin{array}{c}\text { Staphylococcus aureus }(\mathbf{1 6}) \\
\text { Streptococcus pyogenes }(\mathbf{1 9 - 3 2 )} \\
\text { Bacillus cereus }(\mathbf{1 2}, \mathbf{1 3}) \\
\text { Listeria monocytogenes }(\mathbf{1 7 - 1 9 )}\end{array}$ & $\begin{array}{l}\mathrm{IC}_{50}(\mathrm{DPPH}) \\
9.42-12.05 \mathrm{mg} / \mathrm{mL} \\
(\mathrm{RFD} 2-3 \text { and RFD } \\
2-4)\end{array}$ & This study \\
\hline $\begin{array}{l}\text { Thailand } \\
\text { (E. urophylla } \times \text { E. } \\
\text { camaldulensis, RFD } \\
\text { clones) }\end{array}$ & 0.59 & $\begin{array}{c}\text { 1,8-Cineole }(\mathbf{2 3}) \\
\gamma \text {-Terpinene }(\mathbf{1 8}) \\
p \text {-Cymene }(\mathbf{1 4}) \\
\alpha \text {-Terpinyl acetate }(\mathbf{9})\end{array}$ & 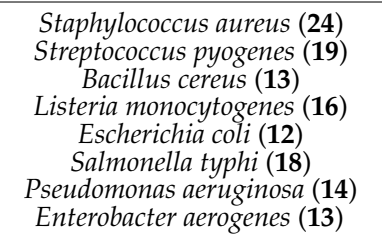 & $\begin{array}{l}\mathrm{IC}_{50}(\mathrm{DPPH}) \\
4.21 \mathrm{mg} / \mathrm{mL}\end{array}$ & This study \\
\hline $\begin{array}{l}\text { Lampang, Thailand } \\
\text { (E. urophylla) }\end{array}$ & 0.6 & $\begin{array}{c}\text { 1,8-Cineole (43) } \\
\gamma \text {-Terpinene (27) }\end{array}$ & $\begin{array}{c}\text { Staphylococcus aureus } \mathbf{( 1 6 )} \\
\text { Bacillus subtilis } \mathbf{( 1 6 )} \\
\text { Escherichia coli } \mathbf{( 1 2 )} \\
\text { Pseudomonas aeruginosa (30) } \\
\text { Staphylococcus intermedius (17) }\end{array}$ & $\begin{array}{c}\mathrm{IC}_{50}(\mathrm{DPPH}) \\
19.95 \mathrm{mg} / \mathrm{mL}\end{array}$ & $\begin{array}{l}\text { Chahomchuen } \\
\text { et al., } 2020 \text { [18] }\end{array}$ \\
\hline $\begin{array}{c}\text { Portugal } \\
\text { (E. urophylla) }\end{array}$ & 0.86 & $\begin{array}{c}\alpha \text {-Phellandrene (45) } \\
\text { 1,8-Cineole (23) }\end{array}$ & - & $\begin{array}{c}\text { TEAC (ABTS) } \\
0.63 \mu \mathrm{mol} \mathrm{TE} / \mathrm{g} \text { EO } \\
{[17]}\end{array}$ & $\begin{array}{l}\text { Faria et al., } \\
2013 \text { [28], } \\
\text { Miguel et al., } \\
2018 \text { [17] }\end{array}$ \\
\hline
\end{tabular}


Table 2. Cont.

\begin{tabular}{|c|c|c|c|c|c|}
\hline Source & $\begin{array}{c}\text { Oil Yield } \\
(\% w / i)\end{array}$ & $\begin{array}{l}\text { Main Terpenoids } \\
\text { (\% Compositions) }\end{array}$ & $\begin{array}{l}\text { Antibacterial Activity } \\
\text { (IZD mm) }\end{array}$ & Antioxidant Activity & Author \\
\hline $\begin{array}{l}\text { Brazil } \\
\text { (E. urophylla) }\end{array}$ & 0.29 & $\begin{array}{l}\text { 1,8-Cineole }(53) \\
\alpha \text {-Pinene }(8)\end{array}$ & Salmonella enteritidis (7) [16] & - & $\begin{array}{c}\text { Batista-Pereira } \\
\text { et al., } 2006 \text { [24], } \\
\text { Ambrosio et al., } \\
2017 \text { [16] }\end{array}$ \\
\hline $\begin{array}{l}\text { Congo } \\
\text { (E. urophylla) }\end{array}$ & 0.53 & $\begin{array}{l}\text { 1,8-Cineole (58) } \\
\alpha \text {-Pinene }(\mathbf{1 0})\end{array}$ & $\begin{array}{c}\text { Bacillus subtilis } \mathbf{( 1 6 )} \\
\text { Escherichia coli }(\mathbf{7 - 1 3}) \\
\text { Klebsiella oxytoca }(\mathbf{1 5}) \\
\text { Klebsiella pneumoniae } \mathbf{( 1 7 )} \\
\text { Proteus vulgaris } \mathbf{( 1 2 )}\end{array}$ & - & $\begin{array}{l}\text { Cimanga et al., } \\
2002[15]\end{array}$ \\
\hline $\begin{array}{l}\text { China } \\
\text { (E. urophylla) }\end{array}$ & 0.04 & $\begin{array}{c}\text { 1,8-Cineole }(63,64) \\
\alpha \text {-Pinene }(11-23) \\
\alpha \text {-Terpinyl acetate }(8)\end{array}$ & - & - & $\begin{array}{l}\text { Li et al., } 2020 \\
{[29]}\end{array}$ \\
\hline $\begin{array}{c}\text { China } \\
(\text { E. urophylla } \times E . \\
\text { camaldulensis })\end{array}$ & 0.16 & $\begin{array}{c}\text { 1,8-Cineole (44) } \\
\text { Limonene (27) } \\
\alpha \text {-Pinene (16) }\end{array}$ & - & - & $\begin{array}{l}\text { Li et al., } 2020 \\
{[29]}\end{array}$ \\
\hline $\begin{array}{l}\text { Côte d'Ivoire } \\
\text { (E. urophylla) }\end{array}$ & 0.4 & $\begin{array}{c}\gamma \text {-Terpinene (23) } \\
p \text {-Cymene (17) } \\
\beta \text {-Pinene (15) } \\
\alpha \text {-Phellandrene (9) }\end{array}$ & - & - & $\begin{array}{l}\text { Coffi et al., } \\
2012 \text { [27] }\end{array}$ \\
\hline $\begin{array}{l}\text { Taiwan } \\
\text { (E. urophylla) }\end{array}$ & 2.2 & $\begin{array}{c}\text { 1,8-Cineole }(58) \\
\alpha \text {-Terpinyl acetate }(\mathbf{1 5})\end{array}$ & - & - & $\begin{array}{l}\text { Cheng et al., } \\
2009 \text { [25] }\end{array}$ \\
\hline $\begin{array}{l}\text { Ethiopia } \\
\text { (E. urophylla) }\end{array}$ & 0.4 & $\begin{array}{c}\text { 1,8-cineole }(\mathbf{3 4}) \\
\alpha \text {-Pinene }(\mathbf{1 3}) \\
\alpha \text {-Terpinyl acetate }(\mathbf{1 2}) \\
\text { Limonene }(\mathbf{1 0})\end{array}$ & - & - & $\begin{array}{l}\text { Dagne et al., } \\
2000[23]\end{array}$ \\
\hline
\end{tabular}

IZD: Inhibition zone diameter. -: no reported.

\subsection{GC/MS Analysis of Eucalypt Oils}

The terpenoid compositions of five eucalypt leaf oils extracted from E. urophylla and E. urophylla $\times$ E. camaldulensis hybrid clones were tentatively identified by comparing their mass spectra with those contained in the NIST 14 mass spectral libraries and comparing the retention indices with those reported in the NIST Chemistry WebBook. The results are presented in Table 1. The relative concentration of all analytical compounds was determined by the percentage composition of each compound corresponding to the total compounds. Sixty-seven terpenoids were identified from the five eucalypt oils at different compositions, corresponding to $99-100 \%$ of the total oil compositions and including monoterpenoids (31.22-80.81\%) and sesquiterpenoids (19.20-68.40\%). These oils contain a high proportion of oxygenated compounds (55.26-77.19\%).

Fifty-seven terpenoids were found in the clonal variation of four E. urophylla essential oils (RFD 2-2, RFD 2-3, RFD 2-4, and RFD 2-6), including monoterpenoids (31.22-68.95\%) and sesquiterpenoids (31.08-68.40\%). Only the essential oil of the RFD 2-4 clone contained more monoterpenes than sesquiterpenes. Among these oils, $61.62-77.19 \%$ were oxygenated terpenoids, with the greatest amount found in the essential oil of the RFD 2-6 clone, while only the essential oils of the RFD 2-3 and RFD 2-4 clones contained 0.48 and $1.08 \%$ phenolic terpenoids, respectively. Their E. urophylla oils were mainly composed of 1,8cineole (16.34-22.75\%), $\alpha$-terpinyl acetate (4.79-7.72\%), $\beta$-caryophyllene (3.82-11.79\%), and spathulenol (2.05-11.93\%). The greatest compositions of $\beta$-caryophyllene and spathulenol were found in the essential oils of RFD 2-3 and RFD 2-6 clones, respectively. In Table 2, the main terpenoid compositions of E. urophylla leaf essential oils compared with those of previous studies are shown. Previous studies have mostly found 1,8-cineole (eucalyptol) to be the main component in E. urophylla leaf essential oils [15,18,23-26,28,29], with the exception of Coffi et al. [27], who found 1,8-cineole to be a minor constituent in these oils.

The leaf essential oil of E. urophylla $\times$ E. camaldulensis hybrid clone (RFD 2-5) contained 39 terpenoids, including monoterpenoids (80.81\%) and sesquiterpenoids (19.20\%). There were $55.26 \%$ oxygenated terpenoids in this oil, with $3.45 \%$ phenolic terpenoids. This essential oil's main constituents were 1,8-cineole (22.72\%), $\gamma$-terpinene $(17.99 \%), p$ cymene (14.34\%), and $\alpha$-terpinyl acetate (8.66\%). Previous studies by Li et al. [29] reported 
1,8-cineole, $\alpha$-pinene, and limonene to be major compounds in the hybrid oil (Table 2). Figure 1 illustrates the terpenoid structures of all the major compounds in the studied eucalypt oils. Previously, our group reported variations in the terpenoid compositions of E. camaldulesis leaf essential oils, which were mainly composed of $p$-cymene, 1,8-cineole, and $\gamma$-terpinene [22]. The terpenoid compositions and dominant constituents of hybrid eucalypt oil are expected to be a mixture of compounds derived from a cross between the parental species. The findings of the research indicated that the terpenoid components in eucalypt oils can vary significantly among clones of the pure species and between the pure and hybrid clones depending on the genetic background of the clones. Moreover, 1,8-cineole was found to be the most abundant in the compositions of all these eucalypt oils. Several studies show that eucalypt oils are greater in oxygenated terpenes, particularly 1,8-cineole, which seems to exhibit antimicrobial activity [1,3,31]. Furthermore, 1,8-cineole has been reported to have therapeutic potency for the treatment of numerous diseases, and no toxicity or carcinogenicity has been reported [32]. Additionally, the eucalypt oils of the clones RFD 2-3 and RFD 2-4, as well as the hybrid clone RFD 2-5, contained phenolic monoterpenes (Figure 1), the greatest amount of which was observed in the oil of the hybrid clone (3.45\%). The phenolic terpenes have been shown to play an important role in the antioxidant effect of E. camaldulensis oils [22].

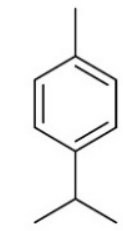

p-Cymene $(14.34 \%)$ $\mathrm{t}_{\mathrm{R}} 11.886 \mathrm{~min}$

(Main monoterpene hydrocarbons found in oil of RFD 2-5)

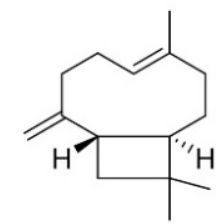

$\beta$-Caryophyllene (8.34-11.79\%) $t_{R} 30.044$ min

(Main sesquiterpene hydrocarbon found in oils of RFD 2-2, RFD 2-3. RFD 2-6)

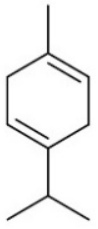

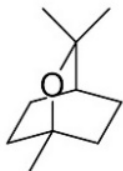

1,8-Cineole (16.34-24.75\%) $t_{R} 12.258$ min

(Main oxygenated monoterpenes found in all oils)

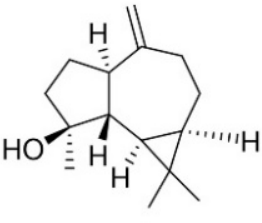

Spathulenol (11.93\%) $t_{R} 36.371 \mathrm{~min}$

(Main oxygenated sesquiterpene found in oil of RFD 2-6)

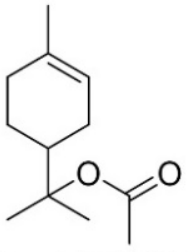

$\mathrm{R}_{\mathrm{R}} 26.944 \mathrm{~min}$<smiles>Cc1ccc(C(C)C)c(O)c1</smiles>

Thymol (0-1.26\%) Carvacrol (0.48-2.19\%) $\left(\mathrm{t}_{\mathrm{R}} 24.086 \mathrm{~min}\right)$

(Antioxidant phenolic monoterpenes found in oils of RFD 2-3. RFD 2-4. RFD 2-5)

Figure 1. Chemical structures of main terpenoids and phenolic terpenoids found in essential oils of the E. urophylla clones (RFD 2-2, RFD 2-3, RFD 2-4, and RFD 2-6) and the E. urophylla $\times$ E. camaldulensis hybrid clone (RFD 2-5) that are important to the bioactivity of oils.

\subsection{Antibacterial Activity of Eucalypt Oils}

The results of an antibacterial agar disc diffusion assay on five Eucalyptus leaf oils against eight pathogenic bacterial strains are shown in Table 3 . The inhibition zone diameter (IZD) was used to evaluate the antibacterial effect, which was classified as follows by Djabou et al. [33]: not sensitive ( - ) for diameters of $\leq 8 \mathrm{~mm}$, moderately sensitive (+) for diameters between 8 and $14 \mathrm{~mm}$, sensitive (++) for diameters between 14 and $20 \mathrm{~mm}$, and extremely sensitive $(+++)$ for diameters of $\geq 20 \mathrm{~mm}$. In all bacterial tests except against Bacillus cereus, there were significant differences in antibacterial effects among the clones $(p<0.05)$. The findings also revealed that the four eucalypt oils of the E. urophylla clones (RFD 2-2, RFD 2-3, RFD 2-4, and RFD 2-6) had stronger antibacterial activity against Gram-positive bacteria than Gram-negative bacteria, whereas the eucalypt oils of the E. urophylla $\times$ E. camaldulensis hybrid clone (RFD 2-5) showed antibacterial effects against 
both Gram-positive and Gram-negative bacteria. All of these oils were extremely effective against Streptococcus pyogenes, with the oil from the RFD 2-2 clone exhibiting the strongest effect and being significantly different from the other oils, but not significantly different from tetracycline, the positive control. The eucalypt hybrid oil was more greatly effective against Staphylococcus aureus than all of the E. urophylla oils. These eucalypt oils also had an effect on Listeria monocytogenes and had a moderate effect against Bacillus cereus. The hybrid oil was also significantly more effective against Gram-negative bacteria, i.e., Escherichia coli, Salmonella typhi, Pseudomonas aeruginosa, and Enterobacter aerogenes than the E. urophylla oils, which were only moderately effective against $S$. typh $i$ and inactive against $P$. aeruginosa and E. aerogenes. Additionally, the bacteriostatic effect of the hybrid oil against $P$. aeruginosa was considerably better than tetracycline. Nonetheless, all eucalypt oils were less effective against $S$. aureus, B. cereus, L. monocytogenes, E. coli, S. typhi, and E. aerogenes than the positive control, tetracycline, which is a board-spectrum antibiotic that has been widely used to treat a variety of clinical infections [34].

Table 3. The inhibition zone diameters (IZDs) of five eucalypt oil against eight bacterial strains.

\begin{tabular}{|c|c|c|c|c|c|c|}
\hline \multirow{2}{*}{ Bacterial Strains } & \multicolumn{6}{|c|}{$\operatorname{IZD}(\mathrm{mm})^{a}$} \\
\hline & RFD 2-2 & RFD 2-3 & RFD 2-4 & RFD 2-6 & RFD 2-5 & Tetracycline $^{b}$ \\
\hline Gram positive & & & & & & \\
\hline $\begin{array}{l}\text { Staphylococcus aureus } \\
\text { (DMST 8840) }\end{array}$ & $16.42 \pm 0.78 c$ & $15.54 \pm 1.45 c$ & $15.77 \pm 0.37 c$ & $16.09 \pm 2.09 c$ & $24.23 \pm 2.27 b$ & $28.33 \pm 2.99 a$ \\
\hline $\begin{array}{l}\text { Streptococcus pyogenes } \\
\text { (DMST 30563) }\end{array}$ & $32.49 \pm 4.61 \mathrm{a}$ & $18.87 \pm 0.94 b$ & $21.26 \pm 2.46 b$ & $21.41 \pm 1.29 b$ & $18.77 \pm 1.49 b$ & $34.30 \pm 2.95 a$ \\
\hline $\begin{array}{l}\text { Bacillus cereus } \\
\text { (DMST 5040) }\end{array}$ & $13.43 \pm 2.11$ & $13.29 \pm 4.65$ & $12.89 \pm 2.54$ & $11.69 \pm 5.09$ & $12.59 \pm 2.94$ & $18.23 \pm 1.59$ \\
\hline $\begin{array}{l}\text { Listeria monocytogenes } \\
\quad \text { (DMST 17303) }\end{array}$ & $19.49 \pm 2.13 b$ & $18.26 \pm 1.90 \mathrm{bc}$ & $17.33 \pm 1.03 b c$ & $17.85 \pm 0.89 b c$ & $15.85 \pm 1.35 c$ & $22.76 \pm 1.13 a$ \\
\hline Gram negative & & & & & & \\
\hline $\begin{array}{l}\text { Escherichia coli } \\
\text { (DMST 4212) }\end{array}$ & $6.00 \pm 0.00 \mathrm{~d}$ & $6.00 \pm 0.00 \mathrm{~d}$ & $8.36 \pm 0.12 c$ & $6.00 \pm 0.00 \mathrm{~d}$ & $11.75 \pm 1.10 b$ & $23.95 \pm 1.60 \mathrm{a}$ \\
\hline $\begin{array}{l}\text { Salmonella typhi } \\
\text { (DMST 5784) }\end{array}$ & $7.87 \pm 1.72 \mathrm{c}$ & $8.35 \pm 2.06 c$ & $10.78 \pm 1.60 c$ & $8.28 \pm 2.05 c$ & $17.97 \pm 2.47 b$ & $28.17 \pm 2.68 a$ \\
\hline $\begin{array}{l}\text { Pseudomonas aeruginosa } \\
\text { (DMST 4739) }\end{array}$ & $6.00 \pm 0.00 \mathrm{~b}$ & $6.00 \pm 0.00 \mathrm{~b}$ & $6.00 \pm 0.00 b$ & $6.00 \pm 00 b$ & $14.41 \pm 5.14 \mathrm{a}$ & $8.53 \pm 1.10 b$ \\
\hline $\begin{array}{c}\text { Enterobacter aerogenes } \\
\text { (DMST 8841) }\end{array}$ & $6.00 \pm 0.00 \mathrm{~d}$ & $6.00 \pm 0.00 \mathrm{~d}$ & $7.71 \pm 0.61 c$ & $6.00 \pm 0.00 \mathrm{~d}$ & $12.69 \pm 2.07 b$ & $17.79 \pm 0.37 a$ \\
\hline
\end{tabular}

${ }^{a}$ IZD includes the diameter of the disc $(6 \mathrm{~mm}) .{ }^{\mathrm{b}}$ Tetracycline was used as a positive control. RFD 2-2, RFD 2-3, RFD 2-4, and RFD 2-6 are E. urophylla oils. RFD 2-5 is the hybrid E. urophylla $\times$ E. camaldulensis oil. Data are represented as the mean $\pm S D$ in triplicate, and different lowercase letters in the same row represent significant difference among clones by Duncan's multiple range test $(p<0.05)$.

The minimum inhibitory concentration (MIC) and minimum bactericidal concentration (MBC) values of the Eucalyptus leaf oils on all test strains were also determined; these values ranged from $<0.06$ to 16.00 and from 0.12 to $32 \mathrm{mg} / \mathrm{mL}$, respectively (Table 4). According to Djabou et al. [33], the results were classified as follows based on the MIC and MBC values expressed in $\mathrm{mg} / \mathrm{mL}$ : not sensitive $(-)$ for values greater than $25.0 \mathrm{mg} / \mathrm{mL}$, moderately sensitive (+) for values between 12.5 and $3.0 \mathrm{mg} / \mathrm{mL}$, sensitive $(++)$ for values between 2 and $0.4 \mathrm{mg} / \mathrm{mL}$, and extremely sensitive $(+++)$ for values equal or less than $0.2 \mathrm{mg} / \mathrm{mL}$. The bacteriostatic effects of the tested eucalypt oils, as evaluated by the MIC and MBC, were related to IZD, with all the E. urophylla oils being more effective against Gram-positive bacteria than Gram-negative bacteria, while the hybrid eucalypt oil was effective against all tested strains. Additionally, the MIC values indicate that all the test oils were extremely sensitive to $S$. pyogenes, similar to the determination of inhibition zones, but the oil from the RFD 2-6 clone had the strongest effect. Based on MIC values, these oils had an effect on Gram-positive bacteria, along with S. aureus, B. cereus, and L. monocytogenes, with the oil from the RFD 2-6 clone having the greatest effect. In the case of Gram-negative bacterial 
strains, only the oil of the hybrid clone (RFD 2-5) was moderately sensitive to all the test strains, whereas the E. urophylla oils had a moderate effect only on $S$. typhi, and the other strains were inactive.

Table 4. The MIC and MBC of five eucalypt oils against eight bacterial strains.

\begin{tabular}{|c|c|c|c|c|c|c|}
\hline \multirow{2}{*}{ Bacterial Strains } & \multicolumn{6}{|c|}{$\mathrm{MIC} / \mathrm{MBC}(\mathrm{mg} / \mathrm{mL})$} \\
\hline & RFD 2-2 & RFD 2-3 & RFD 2-4 & RFD 2-6 & RFD 2-5 & Tetracycline $^{a}$ \\
\hline Gram positive & & & & & & \\
\hline $\begin{array}{l}\text { Staphylococcus aureus } \\
\text { (DMST 8840) }\end{array}$ & $1.0 / 4.0$ & $1.0 / 8.0$ & $2.0 / 8.0$ & $0.5 / 4.0$ & $2.0 / 8.0$ & $<0.0002 / 0.0019$ \\
\hline $\begin{array}{l}\text { Streptococcus pyogenes } \\
\text { (DMST 30563) }\end{array}$ & $0.12 / 0.5$ & $0.12 / 0.25$ & $0.12 / 0.5$ & $<0.06 / 0.12$ & $0.25 / 0.5$ & $<0.0002 / 0.0019$ \\
\hline $\begin{array}{l}\text { Bacillus cereus } \\
\text { (DMST 5040) }\end{array}$ & $0.5 / 2.0$ & $0.5 / 4.0$ & $0.5 / 4.0$ & $0.12 / 1.0$ & $1.0 / 4.0$ & $0.0019 / 0.0156$ \\
\hline $\begin{array}{l}\text { Listeria monocytogenes } \\
\text { (DMST 17303) }\end{array}$ & $0.5 / 1.0$ & $0.5 / 1.0$ & $0.5 / 2.0$ & $0.5 / 0.5$ & $1.0 / 4.0$ & $0.0009 / 0.0078$ \\
\hline Gram negative & & & & & & \\
\hline $\begin{array}{l}\text { Escherichia coli } \\
\text { (DMST 4212) }\end{array}$ & $16.0 / 16.0$ & $16.0 / 16.0$ & $8.0 / 16.0$ & $16.0 / 32.0$ & $8.0 / 8.0$ & $0.0009 / 0.0078$ \\
\hline $\begin{array}{l}\text { Salmonella typhi } \\
\text { (DMST 5784) }\end{array}$ & $4.0 / 8.0$ & $4.0 / 8.0$ & $4.0 / 8.0$ & $4.0 / 8.0$ & $4.0 / 4.0$ & $0.0009 / 0.0078$ \\
\hline $\begin{array}{l}\text { Pseudomonas aeruginosa } \\
\text { (DMST 4739) }\end{array}$ & $8.0 / 16.0$ & $8.0 / 16.0$ & $8.0 / 16.0$ & $8.0 / 16.0$ & $4.0 / 4.0$ & $0.06 />0.25$ \\
\hline $\begin{array}{l}\text { Enterobacter aerogenes } \\
\text { (DMST 8841) }\end{array}$ & $16.0 / 16.0$ & $16.0 / 16.0$ & $16.0 / 16.0$ & $16.0 / 16.0$ & $8.0 / 8.0$ & $0.0078 / 0.125$ \\
\hline
\end{tabular}

There have been a few studies on the antibacterial properties of E. urophylla leaf oil (Table 2). Only S. aureus, E. coli, and P. aeruginosa have been reported as bacteria tested $[15,18]$. However, the antibacterial properties of E. urophylla $\times$ E. camaldulensis hybrid leaf essential oil have not been reported elsewhere.

According to prior studies, Gram-positive bacteria are more susceptible to Eucalyptus oils than Gram-negative bacteria [1]. However, the variability in the antibacterial effects of eucalypt oils could be due to differences in the distribution of their major and minor constituents, the concentration of each component, or a synergetic effect between the constituents within the oils. The antibacterial action of oils is influenced by their hydrophilicity. Gram-positive bacteria have a cell wall composed of peptidoglycan linked with other molecules, such as protein or teichoic acid, while the cell walls of Gram-negative bacteria have an outer membrane made up of lipopolysaccharide (LPS), which acts as a barrier to hydrophilic molecules [35]. Gram-negative bacteria are therefore considered to be more resistant to the effects of essential oils that influence their hydrophilic groups (oxygenated compounds) than Gram-positive bacteria.

Correlations between the antibacterial effects of the five eucalypt oils and their constituents revealed that all essential oils containing high amounts of oxygenated terpenes (55.26-77.19\%) were more effective against Gram-positive bacteria than Gram-negative bacteria. Many previous studies have found that eucalypt oils were higher in 1,8-cineole, which seems to have antibacterial properties $[2,3,15,31,36,37]$. However, the major oxygenated terpenoids in our essential oils, $\alpha$-terpinyl acetate and spathulenol, as well as the minor constituents, borneol, citral, 4-terpineol, $\alpha$-terpineol, thymol, carvacrol, and caryophyllene oxide, have been reported to have antibacterial effects [38-42]. Furthermore, the strongest activity of these oils against $S$. pyogenes was observed, and the oil of the E. urophylla clone (RFD 2-6), with the highest oxygenated terpenes, displayed the highest amount of activity (lowest MIC/MBC value). The findings supported previous reports that essential oils high in 1,8-cineole, $\alpha$-terpinyl acetate, and spathulenol had a strong antibacterial effect against S. pyogenes $[36,43,44]$. Furthermore, the main monoterpene hydrocarbons, $p$-cymene and 
$\gamma$-terpinene, as well as the phenolic terpenoids, carvacrol and thymol, found in the oil of the E. urophylla $\times$ E. camaldulensis hybrid clone, may cause this oil to have bacteriostatic effects against both Gram-positive and Gram-negative bacteria. The antibacterial properties of these compounds, as well as the synergistic effect between carvacrol and cymene, have been reported [38,40-42,45].

\subsection{Antioxidant Activity of Eucalypt Oils}

The antioxidant activities of the clonal variations of four E. urophylla leaf oils and one E. urophylla $\times$ E. camaldulensis hybrid leaf oil were investigated using the DPPH free radical scavenging activity and the ferric reducing antioxidant power (FRAP) assay. With the DPPH assay, the five eucalypt oils were investigated in dose-dependent mode $(0.5-5.0 \mathrm{mg} / \mathrm{mL})$. With increasing concentrations of each eucalypt oil, there was an increase in free radical scavenging activity (\%). Significant differences in antioxidant activity, i.e., DPPH inhibition, $\mathrm{IC}_{50}$, and the FRAP value, among the clones were observed $(p<0.05)$. The inhibition of these oils ranged from $22.56 \pm 1.16$ to $59.14 \pm 1.66 \%$ based on the dose of $5.0 \mathrm{mg} / \mathrm{mL}$. All eucalypt oils had $\mathrm{IC}_{50}$ values ranging from $4.21 \pm 0.35$ to $52.53 \pm 19.96 \mathrm{mg} / \mathrm{mL}$ (Table 5). The activity of all tested oils was lower when compared to a standard synthetic antioxidant compound, such as BHT ( $\mathrm{IC}_{50}$ value of $7.28 \pm 0.47 \mu \mathrm{g} / \mathrm{mL}$ ). The leaf oil of the E. urophylla $\times$ E. camaldulensis hybrid clone (RFD 2-5) had the highest free radical scavenging activity based on DPPH inhibition, which was significantly different from the other oils. Among the oils of the E. urophylla clones, RFD 2-3 and RFD 2-4 exhibited significantly greater DPPH radical scavenging activity compared with that of the RFD 2-2 and RFD 2-6 clones. The FRAP assay is described as a precise method to determine "antioxidant power," with FRAP values calculated by correlating the absorbance change at $593 \mathrm{~nm}$ in sample mixtures to those comprising ferrous ions in a standard solution. The FRAP values of the five eucalypt oils ranged from $103.09 \pm 3.47$ to $337.86 \pm 18.69 \mathrm{mM} \mathrm{Fe}$ (II)/g of oil (Table 5), and these are very low when compared to BHT, a synthetic antioxidant compound. The oil of the hybrid clone (RFD 2-5) had significantly higher FRAP values than the oils of the pure E. urophylla clones. In terms of the pure clone variation, the oil of the RFD 2-3 clone yielded the highest FRAP values related to the DPPH assay.

Table 5. Antioxidant activities of the five eucalypt oils.

\begin{tabular}{|c|c|c|c|}
\hline \multirow[t]{2}{*}{ Eucalypt Oils ${ }^{a}$} & \multicolumn{3}{|c|}{ Antioxidant Activities } \\
\hline & $\%$ DPPH Inhibition ${ }^{b}$ & $\mathrm{IC}_{50}(\mathrm{mg} / \mathrm{mL})$ & FRAP (mM Fe (II)/g of Oil) \\
\hline RFD 2-2 & $28.08 \pm 0.32 c$ & $52.53 \pm 19.96 a$ & $129.38 \pm 5.65 c$ \\
\hline RFD 2-3 & $36.66 \pm 1.22 b$ & $9.42 \pm 0.57 \mathrm{~b}$ & $230.15 \pm 66.14 b$ \\
\hline RFD 2-4 & $36.48 \pm 0.50 b$ & $12.05 \pm 0.51 b$ & $163.96 \pm 4.03 b c$ \\
\hline RFD 2-6 & $22.56 \pm 1.16 \mathrm{~d}$ & $51.59 \pm 27.06 a$ & $103.09 \pm 3.47 \mathrm{c}$ \\
\hline RFD 2-5 & $59.14 \pm 1.66 a$ & $4.21 \pm 0.35 b$ & $337.86 \pm 18.69 a$ \\
\hline
\end{tabular}

${ }^{a}$ Leaf eucalypt oils of the E. urophylla clones (RFD 2-2, RFD 2-3, RFD 2-4, and RFD 2-6) and the E. urophylla $\times$ E. camaldulensis hybrid clone (RFD 2-5). $\mathrm{b} \% \mathrm{DPPH}$ inhibition at $5 \mathrm{mg} / \mathrm{mL}$ of eucalypt oils. As a positive control, BHT was used with an $\mathrm{IC}_{50}$ of $7.28 \pm 0.47 \mu \mathrm{g} / \mathrm{mL}$. Data are represented as mean $\pm \mathrm{SD}$ in triplicate, and different lowercase letters in the same column represent significant difference among clones according to Duncan's multiple range test $(p<0.05)$.

The antioxidant activities of the eucalypt oils from the four E. urophylla clones and the E. urophylla $\times$ E. camaldulensis hybrid clone planted in Thailand's Nakhon Ratchasima province are reported here for the first time. However, there has yet to be a published report on the activity of the E. urophylla $\times$ E. camaldulensis hybrid oil, despite the fact that E. urophylla oil has been reported on by a few other researchers (Table 2). Furthermore, the antioxidant activities of the two E. urophylla oils from the RFD 2-3 and RFD 2-4 clones were greater than that of an E. urophylla oil cultivated in Northern Thailand $\left(\mathrm{IC}_{50} 19.95 \mathrm{mg} / \mathrm{mL}\right)$, reported by Chahomchuen et al. [18]. The difference in eucalypt oil activity could be attributed to differences in phytochemical compositions, which are influenced by genetic background, planting sites, plantation management, and climatic factors. 
The phenolic terpenoids, thymol and carvacrol, are known to be antioxidant active compounds [22]. Our results revealed that the antioxidant property of the studied eucalypt oils was relative to the amount of thymol and carvacrol.

\section{Materials and Methods}

\subsection{Plant Materials}

Four E. urophylla clones and an E. urophylla $\times$ E. camaldulensis hybrid clone developed by the Royal Forest Department (RFD) were selected from a clonal test established in 2010 at the Northeast Forest Research and Development Center in Nakhon Ratchasima province, Thailand $\left(14^{\circ} 28^{\prime} \mathrm{N}, 101^{\circ} 54^{\prime} \mathrm{E}\right)$ [30]. The E. urophylla clones (RFD 2-2, RFD 2-3, RFD 2-4, and RFD 2-6) were developed from a phenotypic selection of the half-sib families (open pollination), while the E. urophylla $\times$ E. camaldulensis hybrid clone (RFD 2-5) was developed from a phenotypic selection of the full-sib families (controlled pollination). Fresh mature leaves of all Eucalyptus clones were collected from planting sites in July 2019 for essential oil extraction.

\subsection{Extraction of Eucalypt Oils}

The dry leaves of the Eucalyptus samples were chopped into small pieces and ground with blenders after a week of air drying. The finely ground leaves ( $30 \mathrm{~g})$ were hydrodistilled for $90 \mathrm{~min}$ in $250 \mathrm{~mL}$ of distilled water. After that, the distillate was extracted with methylene chloride and dried over sodium sulfate anhydrous before the solvent was drained away at low pressure. The eucalypt oil was then obtained and stored in the refrigerator until used. The oil yield was determined from the weight of the oil based on the weight of the dry leaves.

\subsection{Analysis of Eucalypt Oils}

The eucalypt oils were analyzed using a gas chromatography/mass spectrometer (GC/MS), namely, a Shimadzu GC-MS QP2020 with electron impact ionization (70 eV). One microliter of eucalypt oil solution $(20 \mu \mathrm{L} / \mathrm{mL})$ in dichloromethane was injected into a split/splitless inlet at $220^{\circ} \mathrm{C}$ with a split ratio of 1:50. The carrier gas was helium, with a constant flow rate of $1 \mathrm{~mL} / \mathrm{min}$. Compounds were separated on an SH-Rxi-5Sil MS-fused silica capillary column (30 m length $\times 0.25 \mathrm{~mm}$ ID $\times 0.25 \mu \mathrm{m}$ film thickness), with the temperature programmed to start at $60{ }^{\circ} \mathrm{C}$, increase at $3{ }^{\circ} \mathrm{C} / \mathrm{min}$ to $180{ }^{\circ} \mathrm{C}$ and then at $20^{\circ} \mathrm{C} / \mathrm{min}$ to $280^{\circ} \mathrm{C}$, and hold at $280^{\circ} \mathrm{C}$ for $10 \mathrm{~min}$ (with a total run time of $60 \mathrm{~min}$ ). The eluent was forwarded to the mass spectrometer via a transfer line maintained at $280{ }^{\circ} \mathrm{C}$. The temperature of the ion source was $250{ }^{\circ} \mathrm{C}$. The data were collected in scan mode $(\mathrm{m} / \mathrm{z}$ range 45-550) with a 2 min solvent delay. The compounds were analyzed by correlating their mass spectra to those contained in the NIST 14 database. The relative amounts of compounds were calculated in percentages using a normalization method based on the peak area in the total peak chromatogram. The identification of compounds was also confirmed through a comparison of their relation indices relative to n-alkanes $\left(C_{7}-C_{20}\right)$. The retention indices (RI) were calculated in accordance with a series of n-alkanes under the same chromatographic conditions according to Equation (1):

$$
\text { Retention indices }(\mathrm{RI})=\left[n+\left(\frac{t R(s)-t R(n)}{t R(N)-t R(n)}\right)\right] \times 100
$$

where $n$ is the number of carbon atoms, $t_{R}(s)$ is the retention time of the essential oil sample, $t_{R}(n)$ is the retention time of the smaller n-alkane $\left(C_{n}\right)$, and $t_{R}(N)$ is the retention time of the larger n-alkane $\left(C_{n+1}\right)$.

\subsection{Antibacterial Activity}

\subsubsection{Bacterial Strains}

In this study, eight different bacterial strains were used. Four Gram-positive (Staphylococcus aureus DMST 8840, Streptococcus pyogenes DMST 30563, Bacillus cereus DMST 5040, 
and Listeria monocytogenes DMST 17303) and four Gram-negative (Escherichia coli DMST 4212, Salmonella typhi DMST 5784, Pseudomonas aeruginosa DMST 4739, and Enterobacter aerogenes DMST 8841) bacterial strains were received from Thailand's Department of Medical Science, Ministry of Public health, Thailand. Before testing, they were subcultured for $24 \mathrm{~h}$ using brain heart infusion agar (BHA) at $37^{\circ} \mathrm{C}$.

\subsubsection{Determination of Inhibition Zones}

The paper disc agar diffusion method was used to evaluate the eucalypt oil's antibacterial activity [46]. The turbidity standard of $0.5 \mathrm{McFarland}$ was used to adjust the bacterial suspension. Each bacterial suspension was spread onto Mueller-Hinton agar (MH) with a sterile cotton swab. A sample of $10 \mu \mathrm{L}$ was dropped onto a disc with a diameter of $6 \mathrm{~mm}$ (Macherey-Nagel GmbH \& Co., Dueren Germany). Before observing the inhibition zone, the disc was put on the inoculated BHA and incubated for $24 \mathrm{~h}$ at $37^{\circ} \mathrm{C}$. Tetracycline (Oxoid, UK) was used as a control. The inhibition zone diameter (IZD) was measured (mm) in triplicate.

3.4.3. Determination of the Minimum Inhibitory Concentration (MIC) and Minimum Bactericidal Concentration (MBC)

The antibacterial effect of the eucalypt oils was also evaluated by determining the MIC and MBC in accordance with the CLSI, which are the antimicrobial disk susceptibility test standards [46]. In a 96-well microplate, the eucalypt oils were diluted two times to the desired concentrations. After adjusting each tested bacterium to the $0.5 \mathrm{McFarland}$ standard turbidity, the bacterial suspension was diluted 100 times in brain heart infusion broth (BHB). After adding a diluted suspension of $50 \mu \mathrm{L}$ to each well, the microplate was incubated for $24 \mathrm{~h}$ at $37^{\circ} \mathrm{C}$. Tetracycline was used as a positive control. The MIC was defined as the lowest concentration of essential oil that resulted in no visible bacterial growth. The MBC was carried out by culturing $10 \mu \mathrm{L}$ of each clear well on BHA for $24 \mathrm{~h}$ at $37^{\circ} \mathrm{C}$. The $\mathrm{MBC}$ was defined as the lowest concentration of essential oil that showed no bacterial growth. This assay was performed in triplicate.

\subsection{Antioxidant Activity}

\subsubsection{DPPH Radical Scavenging Activity}

The antioxidant properties of eucalypt oils were evaluated using the 2,2-diphenyl1-picrylhydrazyl (DPPH) radical scavenging activity, as previously described [22]. The methanolic solutions of essential oils $(1 \mathrm{~mL})$, ranging in concentration from 1 to $10 \mathrm{mg} / \mathrm{mL}$, were combined with $2 \mathrm{~mL}$ of DPPH methanolic solution $(0.1 \mathrm{mM})$. The mixtures were incubated for $30 \mathrm{~min}$ in a cabinet at room temperature before the absorbance was measured at $517 \mathrm{~nm}$ against a blank. As a positive control, butylated hydroxytoluene (BHT) was used. Equation (2) was used to calculate the \% DPPH of the radicals' inhibition:

$$
\text { DPPH Inhibition }(\%)=\left(A_{b}-A_{o} / A_{b}\right) \times 100
$$

where $A_{b}$ defines the blank's absorbance and $A_{o}$ defines the essential oil's absorbance. The $\mathrm{IC}_{50}$, represented as the oil concentration that inhibits free radicals by $50 \%$, was determined using Probit analysis at a 95\% confidence level [47].

\subsubsection{Ferric Reducing Antioxidant Power (FRAP)}

The FRAP assay was determined using a method previously described [22]. The stock solutions consisted of an acetate buffer (300 mM, pH 3.6), a 2,4,6-tri(2-pyridyl)-s-triazine (TPTZ) solution $(10 \mathrm{mM})$ in hydrogen chloride $(40 \mathrm{mM})$, and ferric chloride $(20 \mathrm{mM})$. The fresh FRAP solution was prepared by combining the acetate buffer, TPTZ, and ferric chloride solutions in a 10:1:1 ratio. The eucalypt oils $(100 \mu \mathrm{L})$ were combined with the FRAP solution $(900 \mu \mathrm{L})$ and left to react in the dark for $30 \mathrm{~min}$ at $37^{\circ} \mathrm{C}$. The resulting ferrous tripyridyl triazine complex was colorimetrically measured at $593 \mathrm{~nm}$. The FRAP value was determined using the calibration curve of ferrous sulfate standard solutions (0.05-1 mM) 
and expressed as milli-molars of Fe (II) per gram of oil. The synthetic antioxidant, BHT, was also analyzed for comparison. The analyses were performed in three replicates, with the average value calculated in each case.

\subsection{Statistical Analysis}

The results of the antibacterial and antioxidant activity tests were represented as mean \pm SD. The analysis of variance (ANOVA) procedure was used to investigate clonal variation in the antibacterial and antioxidant activities, and Duncan's multiple range test, a post hoc test, was performed to determine any significant differences $(p<0.05)$ between clones. The Pearson test was used to analyze the correlation between the two variants. For the statistical analyses, SPSS software (SPSS v.26 for Windows; IBM Crop., Armonk, NY, USA) was used.

\section{Conclusions}

Five eucalypt oils were hydrodistilled from the leaves of four E. urophylla clones (RFD 2-2, RFD 2-3, RFD 2-4, and RFD 2-6) and an E. urophylla $\times$ E. camaldulensis hybrid clone (RFD 2-5). The clear and yellowish eucalypt oils were obtained in a $0.38-0.59 \%$ yield on a dry leaf basis, with the oil yield of the hybrid clone being higher than the pure E. urophylla clones. Based on their chemical compositions, the eucalypt oils obtained in this study were qualitatively and quantitatively showed differences among the E. urophylla clones and hybrid clone. The E. urophylla oils mainly comprised 1,8-cineole, $\alpha$-terpinyl acetate, $\beta$-caryophyllene, and spathulenol, whereas a mixture of compounds from a cross between the parental species made up the major and minor compositions of eucalypt hybrid oil. The antibacterial activities of these oils were investigated, and it was found that all E. urophylla oils were more potent against Gram-positive bacterial strains than Gram-negative bacterial strains, but a eucalypt hybrid oil was effective against all strains tested. Furthermore, S. pyogenes was extremely sensitive to these oils. The oxygenated terpenes, particularly 1,8-cineole, $\alpha$-terpinyl acetate, and spathulenol, may be responsible for these eucalypt oils' strong antibacterial effect against Gram-positive bacteria. The oils of the hybrid clone could also inhibit all Gram-negative bacteria, most probably due to the dominance of monoterpenes, $p$-cymene, and $\gamma$-terpinene, or to a synergistic effect of these and phenolic terpenoids. All eucalypt oils were tested for antioxidant activities, and essential oil from the hybrid eucalypt clone was observed to be more potent than the pure E. urophylla clones. Phenolic terpenoids, such as thymol and carvacrol, may contribute to the antioxidant properties of these oils. Our findings are the first to describe the antibacterial and antioxidant activities of the E. urophylla $\times$ E. camaldulensis hybrid's leaf essential oil.

According to the study's findings, all of the investigated eucalypt oils might be used as a new significant source of natural bioactive agents for healthcare, beauty care, and household products.

Author Contributions: Conceptualization, S.D. and S.L.; methodology, S.L.; software, P.S.; investigation, S.L., N.W., K.B. and T.S.; resources, S.D.; writing-review and editing, S.D. and S.L.; supervision, S.L.; project administration, S.D. and S.L.; funding acquisition, S.D., S.L. and P.S. All authors have read and agreed to the published version of the manuscript.

Funding: This research was funded by the Kasetsart University Research and Development Institute (KURDI) under Contract No. KURDI-3-1(s)83.61. The authors also acknowledge financial support from King Mongkut's University of Technology North Bangkok under Contract No. KMUTNB-64KNOW-17.

Institutional Review Board Statement: Not applicable.

Informed Consent Statement: Not applicable.

Data Availability Statement: Data are contained within the article.

Acknowledgments: The authors would like to thank the Faculty of Science at Sriracha, Kasetsart University, Sriracha Campus, Faculty of Forestry, Kasetsart University, and the Faculty of Science 
at Maejo University, Thailand. The authors would also like to express their sincere appreciation for the RFD and the Northeast Forest Research and Development Center officials who assisted with leaf sample collection in the field.

Conflicts of Interest: The authors declare that there is no conflict of interest.

Sample Availability: Samples of the compounds are available from the authors.

\section{References}

1. Barbosa, L.C.A.; Filomeno, C.A.; Teixeira, R.R. Chemical variability and biological activities of Eucalyptus spp. essential oils. Molecules 2016, 21, 1671. [CrossRef]

2. Dhakad, A.K.; Pandey, V.V.; Beg, S.; Rawat, J.M.; Singh, A. Biological, medicinal and toxicological significance of Eucalyptus leaf essential oil: A review. J. Sci. Food Agric. 2018, 98, 833-848. [CrossRef] [PubMed]

3. Salehi, B.; Sharifi-Rad, J.; Quispe, C.; Llaique, H.; Villalobos, M.; Smeriglio, A.; Trombetta, D.; Ezzat, S.M.; Salem, M.A.; Zayed, A.; et al. Insights into Eucalyptus genus chemical constituents, biological activities and health-promoting effects. Trends Food Sci. Technol. 2019, 91, 609-624. [CrossRef]

4. Kasetsart University Faculty of Forestry. Strategy and Action Plan for the Extension of Integrated Forest Economic Trees (2018-2036); Royal Forest Department: Bangkok, Thailand, 2017; pp. 49-51.

5. Dlamini, L.N.; Pipatwattanakul, D.; Maelim, S. Growth variation and heritability in a second-generation Eucalyptus urophylla progeny test at Lad Krating Plantation, Chachoengsao province, Thailand. Agric. Nat. Resour. 2017, 51, 158-162. [CrossRef]

6. Ishiguri, F.; Diloksumpun, S.; Tanabe, J.; Ohshima, J.; Iizuka, K.; Yokota, S. Among-family variations of solid wood properties in 4-year-old Eucalyptus camaldulensis trees selected for pulpwood production in Thailand. Int. Wood Prod. J. 2017, 8, 36-40. [CrossRef]

7. Siripatanadilok, S.; Duangjai, S. Analysis of Eucalyptus's hybrids using morphological and growth characteristics. Thai J. For. 2005, $24,1-12$.

8. Duangjai, S.; Siripatanadilok, S. Verification of interspecific hybrids between Eucalyptus camaldulensis and Eucalyptus urophylla using DNA fingerprinting. Thai J. For. 2005, 24, 13-25.

9. De Assis, T.F. Production and use of Eucalyptus hybrid for industrial purposes. In Proceedings of the QFRI/CRC-SPF Symposium, Noosa, Australia, 9-14 April 2000; Dungey, H.S., Dieters, M.J., Nikles, D.G., Eds.; Department of Primary Industries: Brisbane, Australia, 2000; pp. 63-74.

10. Wu, K.; Wu, J.; Xu, J.; Gan, S. Cross Breeding in Eucalyptus. For. Res. 1996, 9, 504-509.

11. Chen, J.B.; Li, C.R.; Xiang, D.Y.; Guo, D.Q.; Ren, S.Q.; Deng, Y.H.; Xu, J.M. Heterosis test for Eucalyptus hybrid families including E. urophylla $\times$ E. grandis. J. Southern Agri. 2017, 48, 1858-1862.

12. Dick, G.; Eufrade-Junior, H.J.; Schumacher, M.V.; Azevedo, G.B.; Guerra, S.P.S. Eucalypt clonal hybrid influence the carbon amount of below-ground biomass in oxisol, Brazil. Environ. Sci. Proc. 2021, 3, 53.

13. El Asbahani, A.; Miladi, K.; Badri, W.; Sala, M.; Aït Addi, E.H.; Casabianca, H.; El Mousadik, A.; Hartmann, D.; Jilale, A.; Renaud, F.N.R.; et al. Essential oils: From extraction to encapsulation. Int. J. Pharm. 2015, 483, 220-243. [CrossRef]

14. Batish, D.R.; Singh, H.P.; Kohli, R.K.; Kaur, S. Eucalyptus essential oil as a natural pesticide. Forest Ecol. Manag. 2008, 256, 2166-2174. [CrossRef]

15. Cimanga, K.; Kambu, K.; Tona, L.; Apers, S.; De Bruyne, T.; Hermans, N.; Totte, J.; Pieters, L.; Vlietinck, A.J. Correlation between chemical composition and antibacterial activity of essential oils of some aromatic medicinal plants growing in the Democratic Republic of Congo. J. Ethnopharmacol. 2002, 79, 213-220. [CrossRef]

16. Ambrosio, C.M.S.; de Alencar, S.M.; de Sousa, R.L.M.; Moreno, A.M.; Da Gloria, E.M. Antimicrobial activity of several essential oils on pathogenic and beneficial bacteria. Ind. Crops Prod. 2017, 97, 128-136. [CrossRef]

17. Miguel, M.G.; Gago, C.; Antunes, M.D.; Lagoas, S.; Faleiro, M.L.; Megías, C.; Cortés-Giraldo, I.; Vioque, J.; Figueiredo, A.C. Antibacterial, antioxidant, and antiproliferative activities of Corymbia citriodora and the essential oils of eight Eucalyptus species. Medicines 2018, 5, 61. [CrossRef]

18. Chahomchuen, T.; Insuan, O.; Insuan, W. Chemical profile of leaf essential oils from four Eucalyptus species from Thailand and their biological activities. Microchem. J. 2020, 158, 105248. [CrossRef]

19. Asiaei, E.O.; Moghimipour, E.; Fakoor, M.H. Evaluation of antimicrobial activity of Eucalyptus camaldulensis essential oil against the growth of drug-resistant bacteria. Jundishapur J. Nat. Pharm. Prod. 2018, 13, e65050.

20. Sabo, V.A.; Knezevic, P. Antimicrobial activity of Eucalyptus camaldulensis Dehn. plant extracts and essential oils: A review. Ind. Crops Prod. 2019, 132, 413-429. [CrossRef] [PubMed]

21. Limam, H.; Jemaa, M.B.; Tammar, S.; Ksibi, N.; Khammassi, S.; Jallouli, S.; Re, G.D.; Msaada, K. Variation in chemical profile of leaves essential oils from thirteen Tunisian Eucalyptus species and evaluation of their antioxidant and antibacterial properties. Ind. Crops Prod. 2020, 158, 112964. [CrossRef]

22. Diloksumpun, S.; Jeenho, P.; Namkhot, S.; Saleepochn, T.; Luangkamin, S. Potent antioxidant activities of half-sib families of Eucalyptus camaldulensis Dehnh. leaf essential oils planted in Thailand and their antioxidative components. Chiang Mai J. Sci. 2021, $48,112-122$. 
23. Dagne, E.; Bisrat, D.; Alemayehu, M.; Worku, T. Essential oils of twelve Eucalyptus Species from Ethiopia. J. Essent. Oil Res. 2000, 12, 467-470. [CrossRef]

24. Batista-Pereira, L.G.; Fernandes, J.B.; Corrêa, A.G.; da Silva, M.F.G.F.; Vieira, P.C. Electrophysiological responses of Eucalyptus Brown Looper Thyrinteina arnobia to essential oils of seven Eucalyptus species. J. Braz. Chem. Soc. 2006, 17, 555-561. [CrossRef]

25. Cheng, S.S.; Huang, C.G.; Chen, Y.J.; Yu, J.J.; Chen, W.J.; Chang, S.T. Chemical compositions and larvicidal activities of leaf essential oils from two eucalyptus species. Biores. Technol. 2009, 100, 452-456. [CrossRef] [PubMed]

26. Traoré, N.; Sidibé, L.; Figuérédo, G.; Chalchat, J.-C. Chemical composition of five essential oils of Eucalyptus species from Mali: E. houseana F.V. Fitzg. ex Maiden, E. citriodora Hook., E. raveretiana F. Muell., E. robusta Smith and E. urophylla S.T. Blake. J. Essent. Oil Res. 2010, 22, 510-513. [CrossRef]

27. Coffi, K.; Soleymane, K.; Harisolo, R.; Balo, T.B.; Claude, C.J.; Pierre, C.; Gilles, F.; Antoine, A.C. Monoterpene hydrocarbons, major components of the dried leaves essential oils of five species of the genus Eucalyptus from Côte d'Ivoire. Nat. Sci. 2012, 4 , 106-111. [CrossRef]

28. Faria, J.M.S.; Barbosa, P.; Bennett, R.N.; Mota, M.; Figueiredo, A.C. Bioactivity against Bursaphelenchus xylophilus: Nematotoxics from essential oils, essential oils fractions and decoction waters. Phytochemistry 2013, 94, 220-228. [CrossRef]

29. Li, A.; Wu, H.; Feng, Y.; Deng, S.; Hou, A.; Che, F.; Liu, Y.; Geng, Q.; Ni, H.; Wei, Y. A strategy of rapidly screening out herbicidal chemicals from Eucalyptus essential oils. Pest Manag. Sci. 2020, 76, 917-927. [CrossRef]

30. Department of Agriculture Home Page. Available online: https://www.doa.go.th/pvp/wp-content/uploads/2019/11/ AnnoDOA_PublicNo.62.pdf (accessed on 23 November 2021).

31. Marzoug, H.N.B.; Romdhane, M.; Lebrihi, A.; Mathieu, F.; Couderc, F.; Abderraba, M.; Khouja, M.L.; Bouajila, J. Eucalyptus oleosa essential oils: Chemical composition and antimicrobial and antioxidant activities of the oils from different plant parts (stems, leaves, flowers and fruits). Molecules 2011, 16, 1695-1709. [CrossRef]

32. Bhowal, M.; Gopal, M. Eucalyptol: Safety and pharmacological profile. RGUHS J. Pharm. Sci. 2015, 5, 125-131. [CrossRef]

33. Djabou, N.; Lorenzi, V.; Guinoiseau, E.; Andreani, S.; Giuliani, M.C.; Desjobert, J.M.; Bolla, J.M.; Costa, J.; Berti, L.; Luciani, A.; et al. Phytochemical composition of Corsican Teucrium essential oils and antibacterial activity against foodborne or toxi-infectious pathogens. Food Control. 2013, 30, 354-363. [CrossRef]

34. Chopra, I.; Roberts, M. Tetracycline antibiotics: Mode of action, applications, molecular biology, and epidemiology of bacterial resistance. Microbiol. Mol. Biol. Rev. 2001, 65, 232-260. [CrossRef]

35. Nazzaro, F.; Fratianni, F.; De Martino, L.; Coppola, R.; De Feo, V. Effect of essential oils on pathogenic bacteria. Pharmaceuticals 2013, 6, 1451-1474. [CrossRef] [PubMed]

36. Rasooli, I.; Shayegh, S.; Astaneh, S.D.A. The effect of Mentha spicata and Eucalyptus camaldulensis essential oils on dental biofilm. Int. J. Dent. Hyg. 2009, 7, 196-203. [CrossRef] [PubMed]

37. Diriye, M.A.; Ali, M.M.; Ishag, O.A.; Mohamed, M.A. Chemical composition and antimicrobial activity of essential oils extracted from Eucalyptus camaldulensis leaves grown in Sudan. Red Sea Univ. J. Basic Appl. Sci. 2017, 2, 244-253.

38. Ait-Ouazzou, A.; Cherrat, L.; Espina, L.; Lorán, S.; Rota, C.; Pagán, R. The antimicrobial activity of hydrophobic essential oil constituents acting alone or in combined processes of food preservation. Innov. Food Sci. Emerg. Technol. 2011, 12, 320-329. [CrossRef]

39. Bougatsos, C.; Ngassapa, O.; Runyoro, D.K.B.; Chinou, I.B. Chemical composition and in vitro antimicrobial activity of the essential oils of two Helichrysum species from Tanzania. Z. Naturforsch. 2004, 59c, 368-372. [CrossRef] [PubMed]

40. Oyedemi, S.O.; Okoh, A.I.; Mabinya, L.V.; Pirochenva, G.; Afolayan, A.J. The proposed mechanism of bactericidal action of eugenol, $\propto$-terpineol and $g$-terpinene against Listeria monocytogenes, Streptococcus pyogenes, Proteus vulgaris and Escherichia coli. Afr. J. Biotechnol. 2009, 8, 1280-1286.

41. Tzakou, O.; Skaltsa, H. Composition and antibacterial activity of the essential oil of Satureja parnassica subsp. parnassica. Planta Med. 2003, 69, 282-284. [CrossRef] [PubMed]

42. Burt., S. Essential oils: Their antibacterial properties and potential applications in foods-a review. Int. J. Food Microbiol. 2004, 94 223-253. [CrossRef]

43. Yang, J.K.; Choi, M.S.; Seo, W.T.; Rinker, D.L.; Han, S.W.; Cheong, G.W. Chemical composition and antimicrobial activity of Chamaecyparis obtusa leaf essential oil. Fitoterapia 2007, 78, 149-152. [CrossRef]

44. Naz, T.; Packer, J.; Yin, P.; Brophy, J.J.; Wohlmuth, H.; Renshaw, D.E.; Smith, J.; Elders, Y.C.; Vemulpad, S.R.; Jamie, J.F. Bioactivity and chemical characterisation of Lophostemon suaveolens-An endemic Australian Aboriginal traditional medicinal plant. Nat. Prod. Res. 2016, 30, 693-696. [CrossRef] [PubMed]

45. Rattanachaikunsopon, P.; Phumkhachorn, P. In vitro study of synergistic antimicrobial effect of carvacrol and cymene on drug resistant Salmonella typhi. Afr. J. Microbiol. Res. 2009, 3, 978-980.

46. CLSI. Performance Standards for Antimicrobial Disk Susceptibility Tests, Approved Standard, 7th ed.; CLSI document M02-A11; Clinical and Laboratory Standards Institute: Wayne, PA, USA, 2012.

47. Finney, D.J. Probit Analysis; Cambridge University Press: Cambridge, UK, 1952 